\title{
VANHAT NAISET
}

\section{IKÄIHMISTEN YLIOPISTOSSA}

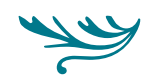

HELSINGIN SANOMAT uutisoi viime syyskuussa (19.9.2010): "Ikääntyvät naiset täyttävät teatterit, konsertit ja kirjallisuuspiirit. Harrastaminen tuo iloa ja keskimäärin kolme elinvuotta lisää.” Artikkelissa kerrotaan, että sosiaalinen osallistuminen edistää terveyttä ja pidentää ikää tehokkaammin kuin liikunta, laihduttaminen tai tupakoinnin lopettaminen. Sosiaalinen hyvinvointi lisää fysiologista hyvinvointia.

Aihetta konkretisoidaan artikkelissa esittelemällä 83-vuotiaan naisen viikko-ohjelma. Viikko täyttyy teatteripiiristä, kirjallisuuspiiristä, kulttuuripiiristä, ikäihmisten yliopistosta, aamu-uinnista, tuolijumpasta, teatterista, puutarhanhoidosta, vapaaehtoistyöstä sekä kyläilystä ja illanvietosta naistuttavien kanssa. Viikkoon mahtuu myös yksi vapaapäivä - lauantai - joka on pyhitetty kuntoilulle, mökille ja perheen kanssa seurustelulle.

Artikkeli nostaa esiin tutkimukseni kannalta keskeisen ilmiön - aktiivisen vanhenemisen - ja sen suhteen 2000-luvulla vilkkaana käyneeseen keskusteluun ikääntyvästä yhteiskunnasta. 83-vuotiaan naisen hengästyttävä viikko-ohjelma ei jätä epäilystä, etteikö tämä nainen vanhenisi nimenomaan aktiivisena. Selväksi käy myös se, että aktiivinen vanheneminen on myönteistä ja ihailtavaa. ja se näyttäytyy yhteiskunnan kannalta suotuisana, jopa suotavana.

Artikkeli on osuva esimerkki tavasta, jolla ikääntyvän yhteiskunnan kannalta myönteistä vanhenemista mediassa esitetään. Käytetyt puhe- ja esitystavat tuottavat ihanteita ja luovat normeja siitä, mitä on onnistunut vanheneminen. Onnistunut yhteiskun- taa säs̈stävä vanheneminen, "oikealla tavalla" vanheneminen, on nimenomaan aktiivisena vanhenemista. Samalla tuotetaan käsityksiä siitä, mikä on "vähemmän suotavaa" tai "väärällä tavalla" vanhenemista.

Ikääntyminen ja eläkkeellä oleminen on poliittista. Ei ole yhdentekevää, miten ja mihin aikansa käyttää - edes eläkkeellä.

Mutta miten he, jotka "täyttävät teatterit, konsertit ja kirjallisuuspiirit", siis vanhat naiset, itse kokevat harrastamisensa? Miten harrastajiksi päädytään? Mikä saa naiset jatkamaan harrastamista vuodesta toiseen? Millainen merkitys näillä "riennoilla" on naisille itselleen? Tutkimuksessani olin kiinnostunut nimenomaan naisten näkökulmasta ja siitä, miten ristiriitaiset julkiset keskustelut aktiivisesta vanhenemisesta ja ikääntyvästä yhteiskunnasta näyttäytyvät, kun niitä tarkastelee arjen tasolla elettyinä.

Koulutussosiologina olen lähestynyt näitä kysymyksiä opiskelun kautta. Opiskelu, ja laajemmin ottaen elinikäinen oppiminen, on ollut ikääntyvän yhteiskunnan yksi keskeisistä puheenaiheista ja tarjotuista ongelmanratkaisutavoista. Olen tarkastellut ikäihmisten yliopistossa opiskelua nimenomaan ikääntyvään yhteiskuntaan osallistumisen tapana. Ikäihmisten yliopistossa opiskelevien naisten haastatteluihin, ikäihmisten yliopistoa käsittelevään dokumenttiaineistoon ja omakohtaisiin ikäihmisten yliopistoa koskeviin havainnointeihin perustuen olen analysoinut sitä, millaista ikäihmisten yliopistossa opiskelu on naisopiskelijalle, osana hänen mennyttä elämänkulkuaan ja nykyistä arkeaan. 
En tyytynyt kysymään vain naisten tulkintoja ja kokemuksia opiskelusta itsestään, vaan tarkastelin aineistojeni sallimissa rajoissa myös opiskelun käytäntöjä, ikäihmisten yliopiston toimintakulttuuria, opiskelua osana laajempaa yliopistoyhteisöä ja perhe- ja ystävyyssuhteita. Näiden tarkastelujen kautta pyrin hahmottamaan sitä, mitä tapahtuu siinä prosessissa, jossa ikääntyvään yhteiskuntaan, aktiiviseen vanhenemiseen ja elinikäiseen oppimiseen liittyvät yhteiskunnalliset keskustelut kohtaavat ikäihmisten yliopistossa henkilökohtaisen ja ruumiillisen kanssa.

\section{TOIMIJUUS JA YHTEISKUNNALLISET EROTTELUT}

Keskeinen osa tutkimustani on sen pohtiminen, millaisin teoreettisin välinein on hedelmällistä lähestyä kysymystä myöhemmän iän opiskelusta ikääntyvään yhteiskuntaan osallistumisen tapana. Lähtökohtanani on käsitys siitä, että ikääntyvään yhteiskuntaan osallistutaan toimimalla erilaisissa instituutioissa, yhteisöissä ja sosiaalisissa suhteissa. Tätä toimintaa ja toiminnallisia prosesseja tarkastelen tutkimukseni keskeisen käsitteen - toimijuuden - avulla.

Toimijuudella ymmärrän käsitystä omista mahdollisuuksista ja rajoituksista toimia. Tämä käsitys, ja siten siis toimijuus, muotoutuu rakenteiden, instituutioiden ja yhteisöjen, niihin kiinnittyvien käytäntöjen, normien ja odotusten sekä tietyllä tavalla resursoidun yksilön välisessä suhteessa. Konkreettisesti tutkin sitä, millaisten prosessien, neuvottelujen ja asettumisten kautta ikäihmisten yliopistossa opiskelevien naisten käsitys ja tunne omista mahdollisuuksistaan ja rajoituksistaan toimia rakentuu.

Keskityin erityisesti siihen, miten yhteiskunnalliset erot - sukupuoli, ikä ja yhteiskuntaluokka - osallistuvat toimijuuden prosesseihin. Ne vaikuttavat ensinnäkin siihen, millaisia yleisiä odotuksia eri-ikäisille miehille ja naisille asetetaan ja millaisiksi odotukset erilaisissa instituutioissa ja yhteisöissä muotoutuvat. Toiseksi sukupuoli, ikä ja yhteiskuntaluokka vaikuttavat yksilön käytössä oleviin resursseihin ja sitä kautta sekä yksilön käsitykseen omista mahdollisuuksistaan ja rajoituksistaan toimia.

Hahmotan sitä, miten ikääntymiseen liittyvät kulttuurisesti ja historiallisesti muokkautuneet jä- sennystavat kehystävät ikääntyneiden arkea, sosiaalisia suhteita, institutionaalisia asemia ja yhteiskunnallisen osallistumisen mahdollisuuksia. Teoreettisemmin ilmaistuna kyse on siitä, miten diskurssit ja käytännöt muotoilevat subjekteja ja määrittävät sitä, millaisina vanhoina naisina voidaan olla olemassa ikääntyvässä yhteiskunnassa.

Yhteiskunnallisista eroista kiinnostuneena tutkijana myös ajattelen, että purkamalla myöhemmän iän opiskelua institutionaalisena ja yhteisöllisenä toimintana on mahdollisuus päästä käsiksi siihen, miten erilaisia eroja tuotetaan ja ihmisiä paikannetaan rutiininomaisesti muun muassa ikään, sukupuoleen ja yhteiskuntaluokkaan liittyvien kulttuuristen itsestäänselvyyksien pohjalta.

\section{OPISKELUN ARKEA IKÄIHMISTEN YLIOPISTOSSA}

Tutkimuksessani käy ilmi, että ikäihmisten yliopistossa opiskelu on naisille tärkeää, jopa niin tärkeää, että ikääntyneen naisen kulttuurisesti ensisijaiseksi nähdyt lastenlasten hoitovelvoitteet järjestetään opiskelun ehdoilla. Naiset haluavat kartuttaa yleissivistystä ja kuulua samanhenkisten ikäihmisten yhteisöön. Opiskelulla tavoitellaan myös aktiivista yhteiskunnan jäsenyyttä. Tämä tarkoittaa sekä pyrkimystä ymmärtää uuden tiedon avulla yhteiskunnallisia muutoksia että halua toimia samoissa paikoissa muiden ikäryhmien kanssa, siis välttää eristäytymistä vain ikäihmisten keskinäisiin ryhmiin.

Opiskelu samanhenkisten ikäihmisten ja erityisesti naisten muodostamassa yhteisössä on aineistoni naisista mukavaa ja se koetaan voimaannuttavana. Yhdessä tekemistä ja viihtymistä korostetaan ikäihmisten yliopiston keskeisenä piirteenä, vaikka sosiaalisten suhteiden etsimistä tai ihmisten tapaamista ei pidetäkään varsinaisena opiskelun motiivina.

Mutta ei opiskelu ole naisille vain mukavaa, voimaannuttavaa tai helppoa. Myös ikäihmisten yliopiston yhteisössä on omat sisäänpäin lämpiävyytensä, sisä- ja ulkopiirinsä. Toimintakulttuuriin kytkeytyviin opiskelijakategorisointeihin liittyen muun muassa seminaariopiskelun ja luennolla käymisen rajaa vartioidaan hanakasti, akateemisia toimintatapoja hallitsemattomia opiskelijoita katsotaan vinoon ja henkisen toimintakyvyn heikkenemistä siedetään huonosti. 
Myös ikäihmisten yliopiston virallinen taso kohdistaa haasteita erityisesti naisopiskelijoille. Naisenemmistöinen opiskelijaprofiili nähdään ongelmallisena, mikä laittaa naisopiskelijoita ottamaan kantaa sukupuoleensa.

Opiskelun arjen ristiriitaisuus jatkuu myös ikäihmisten yliopiston ulkopuolella osana yliopistoyhteisöä ja omia perhe- ja ystävyyssuhteita. Yliopistolla luentosalien ja pienryhmätilojen läheisyydessä sijainnut kahvila oli tutkimukseni naisille yhtä aikaa sekä tärkeäksi että hämmentäväksi koettu paikka. Kahvila tarjosi ikäihmisten yliopiston opiskelijoille mielekkään informaalin toiminta-areenan ja väylän osallistua koko yliopistoyhteisön arkeen. Toisaalta nuorten tutkinto-opiskelijoiden kohtaamisen myötä alettiin pohtia oman opiskelun poikkeavuutta iän mukaisesta normatiivisesta yliopisto-opiskelusta.

Myös ikäihmisten yliopisto-opiskelijoiden keskinäisissä suhteissa rakentui erityisesti yhteiskuntaluokkaan kytkeytyviä erontekoja. Muun muassa käytettyihin puhetapoihin ja pukeutumiseen, yliopistolla opiskelun itsestään

\section{"IKÄIHMISTEN YLIOPISTOSSA} OPISKELU ON NAISILLE NIIN TÄRKË̈̈̈, ETT $\ddot{A}$ MUUN MUASSA LASTENLAPSIIN LIITTYV ̈̈T HOITOVELVOITTEET JÄRJESTETTIIN OPISKELUN EHDOILLA."
OPISKELEMASSA - TAVALLAAN

Olen nimennyt tutkimukseni otsikolla Opiskelemassa tavallaan: Vanhat naiset ikäihmisten yliopistossa. Pääotsikko kiteyttää tutkimukseni tulosten kannalta jotakin hyvin keskeistä. Naisten opiskelu ikäihmisten yliopistossa on opiskelua "tavallaan", koska ikäihmisten yliopiston toimintakulttuurissa on erilaisia tapoja opiskella. Tutkimukseeni osallistuneet naiset kuuluivat ikäihmisten yliopiston sisäpiiriin ja tutkimuksessani piirtynyt kuva ikäihmisten yliopistossa opiskelusta on nimenomaan sisäpiirissä opiskelevien kuva.

Toiseksi, kun naisten opiskelua tarkastelee osana heidän yliopiston ulkopuolista arkeaan ja ihmissuhteitaan, näyttäytyy naisten opiskelu "tavallaan" opiskeluna. Perhe- ja erityisesti ystäväpiireissä opiskelua pidetään eläkkeelle siirtyneelle epätyypillisenä harrastuksena. Siten opiskelu nähdään asiana, josta ei ollut syytä tehdä erityistä numeroa.

Kolmanneksi laajemmassa kulttuurisessa mielessä vanhojen naisten opiskelu on opiskelua "vain tavallaan", koska se rikkoo vallalla olevaa käsitystä opiskelusta työelämään johdattavana tai sitä hyödyntävänä toimintana. Tämä siis siitäkin huolimatta, että elinikäisestä oppimisesta puhuttaessa keskeistä on korostaa opiskelullisen aktiivisuuden kuulumista kaikenikäisille.

Tutkimukseeni osallistuneilla naisilla ei ole iästään ja osin sukupuolestaan johtuen täysimääräistä pääsyä opiskelijaksi. Opiskelun arki vaatii ristiriitaisten tilanteiden sietämistä. Ristiriitoja tuottavat sekä käsitykset yliopistosta nuorten aikuisten koulutuspaikkana että mielikuvat vanhasta naisesta pääasiassa kodin piiriin kuuluvana toimijana. Opiskelu on elinikäisen oppimisen puheista huolimatta vanhoille epätyypillistä toimintaa, jota toteuttaessa joutuu käsittelemään ajatusta itsestä normien vastaisena toimijana sekä kohtaamaan eriasteista ihmettelyä, jopa avointa syrjintää. 


\section{AKTIIVINEN VANHENEMINEN JA IKÄÄNTYVÄ YHTEISKUNTA}

Tutkimukseni antaa aihetta kahden merkittävän huomion tekemiseen. Se osoittaa ensinnäkin, ettei elinikäinen oppiminen ei ole iän suhteen neutraali. Elinikäinen oppiminen määrittyy niin yleisissä keskusteluissa kuin tutkimuksessakin pitkälti työelämänikäisenä oppimisena. Elinikäisen oppimisen yhteiskunnallisena tavoitteena on ikääntyneiden osalta nimenomaan työssä jaksaminen. Työmarkkinoiden ulkopuolelle asettuva vanhuuden elämänvaihe rajautuu näin ollen ulkopuolelle. Vanhuudessa harjoitetusta opiskelusta tuotetaan marginaalista toimintaa. Elinikäisen oppimisen ikäperustaisuudessa ei ole kyse vain arvonannoista, vaan sillä on myös materiaalisia seurauksia opiskeleville ikäihmisille, erityisesti naisille. On mielestäni paikallaan kysyä, kuinka mielekäs tällainen kapea elinikäisen oppimisen käsitys on ja jos se mielekkääksi koetaan, olisiko silloin syytä myös tarkistaa, millaisia lupauksia elinikäiseen oppimiseen kytketään.

Toiseksi tutkimukseni osoittaa, että ikääntyvän yhteiskunnan näkökulmasta "oikealla tavalla" vanheneminen ei ole kaikille samalla tavalla mahdollista, vaikka ulkoiset seikat, kuten taloudelliset, sosiaaliset ja kulttuuriset resurssit, sekä yksilön omat pyrkimykset niin antaisivatkin olettaa. Julkisessa keskustelussa laajalti viljelty ikääntymisen ongelmapuhe siirtää vastuuta ikääntyvän yhteiskunnan taloudellisista ja terveydenhuollollisista haasteista ikäihmisille itselleen. Onnistunut yhteiskuntaa säästävä vanheneminen on nimenomaan aktiivista vanhenemista ja opiskelu on yksi aktiivisen vanhenemisen toteuttamisen tapa. Tutkimukseeni osallistuneiden naisten opiskelun arki ei kuitenkaan vastaa niitä oletuksia aktiivisista ikäihmisistä, joita onnistuneesta vanhenemisesta ja elinikäisestä oppimisesta käydyissä julkisissa keskusteluissa tuotetaan. Alussa viittaamani Helsingin Sanomien artikkeli on tästä hyvä esimerkki.

Aktiivisen vanhenemisen nostaminen osaksi ikääntyvän yhteiskunnan kansantaloudellisia paineita on vaarassa tuottaa nykyistä vahvempaa polarisaatiota ikäihmisten välille. Erojen rakentumista ei tule mieltää vain toimintakyvyllisten mahdollisuuksien kautta eli polarisaation syvenemisenä niiden välillä, jotka ovat terveitä tai jotka eivät ole terveitä. Myös niiden ikäihmisten joukossa, kuten haastattelemani naiset, joilla on resursseja investoida aktiiviseen vanhenemiseen, mahdollisuudet investointien tekemiseen eivät ole tasavertaiset.

Aktiivisuus muotoutuu nimenomaan toimintaan - kuten opiskeluun - kytkeytyvien erontekojen kehyksessä. Kun aktiivisesta vanhenemisesta puhutaan irrallaan yhteiskunnallisista rakenteista ja institutionaalisista käytännöistä, häivytetään samalla näkyvistä olemassa olevia yhteiskuntaluokan, iän ja sukupuolen suhteita ja niiden osallisuutta erontekoihin. Näin ollen näkymättömiin jää myös se, miten mahdollisuudet aktiivisen vanhenemisen toteuttamiseen eriytyvät nimenomaan sosiaalisesti ja kulttuurisesti.

On tärkeää muistaa, että yhteiskunnalliset rakenteet ja kulttuuriset käytännöt ohjaavat ihmisten valintoja ja toimintaa. Siksi aktiivinen vanheneminen ei synny vain yksilön valinnoista. Yhteiskunnallisia ja kulttuurisia ehtoja tarkastelemalla voidaan tuottaa tietoa siitä, millaisin tavoin ehdot formuloituvat ikääntyneiden elämässä ja millaisia rajoja ja mahdollisuuksia ne toimijuudelle asettavat. Tämä tieto on tärkeää sekä koulutuspolitiikan että laajemman vanhenevan väestön määrän kasvuun reagoimaan pyrkivän yhteiskuntapolitiikan kannalta. Se, millaisin tavoin tiedämme ikäihmisistä, vaikuttaa siihen, millaisena ikäihmisenä on mahdollista olla olemassa ikääntyvässä yhteiskunnassa.

Lectio praecursoria (lyh.) Hanna Ojalan väitöstilaisuudessa (aikuiskasvatus) 15.1.2011 Tampereen yliopistossa

Ojala, Hanna (2010). Opiskelemassa tavallaan. Vanhat naiset ikäihmisten yliopistossa. Tampere University Press, Tampere.

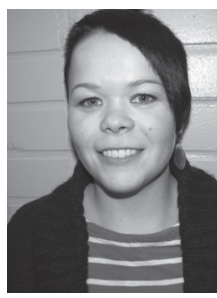

Hanna Ojala

$K T$, yliopistolehtori naistutkimus, Tampereen yliopisto 